\title{
PATTERNS OF FOREST LOSS PER TERRITORIAL CATEGORY IN THE AMAZON RAINFOREST: PERU (2001-2016)
}

\author{
Ethel Rubin-de-Celis-Llanos ${ }^{1 *}$, Zoila A. Cruz-Burga ${ }^{1}$, María de los Ángeles La Torre-Cuadros ${ }^{3}$, Nelson Carlos \\ Rosot $^{2}$, Ana Paula Dalla Corte ${ }^{2}$, Hideo Araki ${ }^{4}$ \\ ${ }^{1}$ Grupo de Investigación Sistemas Socioecológicos y Servicios Ecosistémicos. Facultad de Ciencias Forestales, Universidad Nacional \\ Agraria La Molina (UNALM). Lima 12, Perú. erubin@lamolina.edu.pe*, zcruz@lamolina.edu.pe \\ ${ }^{2}$ Universidade Federal do Paraná. Programa de PósGraduação em Engenharia Florestal. Sector de Ciências Agrárias. Curitiba, Brasil. \\ nelson.rosot@gmail.com, anapaulacorte@gmail.com \\ ${ }^{3}$ Facultad de Ciencias Ambientales, Universidad Científica del Sur. Lima 42, Perú. mlatorrec@ ucientifica.edu.pe \\ ${ }^{4}$ Universidade Federal do Paraná. Sector de Ciências da Terra. Departamento de Geomática. Curitiba, Brasil. haraki@ufpr.br
}

Recebido para publicação: 27/06/2018 - Aceito para publicação: 14/03/2019

\begin{abstract}
Resumo
Padrões de perdas florestais em categorias territoriais de florestas amazônicas: Peru (2001-2016). O objetivo deste trabalho foi analisar o padrão de perda de floresta de 16 categorias territoriais em dois tipos de posse de terra (pública e privada) e da administração (pública e privada) nas florestas amazônicas do Peru entre 2001 e 2016. Através de análises descritivas e análises multivariadas utilizando os cálculos oficiais de perdas florestais definidos pelo Estado peruano, detectou-se um aumento progressivo na perda florestal, sendo os picos mais altos durante os anos de 2009, 2014 e 2016. As regiões de San Martín, Loreto e Ucayali são as que têm a maior perda. As três categorias territoriais com maior perda de floresta foram as não categorizadas (NC), denominadas comunidades nativas (CNT) e propriedades rurais (PR). É evidente que a categoria NC não afeta a tendência geral do desmatamento no país, a dinâmica da perda florestal é similar a outras categorias territoriais com direitos atribuídos.

Palavras-chave: análise multivariada, mudança no uso da terra, desmatamento, posse.
\end{abstract}

\section{Abstract}

The objective of the present study was to analyze the patterns of forest loss in the Peruvian Amazon between 2001 and 2016 according to 16 territorial categories and two types of land tenure (public and private) and administration (public and private). Through descriptive analysis and multivariate analysis using official forest loss data provided by the Peruvian government, a progressive increase in forest loss was detected over time, with the highest peaks in 2009, 2014, and 2016. The departments of San Martín, Loreto, and Ucayali presented the greatest loss. The three territorial categories with the greatest forest loss were the noncategorized areas (NCs), indigenous communities with land titles (ICTs), and rural lands (RLs). The NC category did not affect the general tendency of deforestation in Peru given that the forest loss dynamics in this category were similar to those of other territorial categories with assigned land rights.

Key words: multivariate analysis, land-use change, deforestation, land tenure.

\section{INTRODUCTION}

The Amazon rainforest covers an area of 7.5 million $\mathrm{km}^{2}$, extending across eight countries (OTCA, 2014). Approximately half of this forest is located within a network of 2,954 indigenous territories and natural protected areas (WALKER et al., 2014). In 2013, an estimated 13\% of the original forest cover had been lost. The countries with the highest percentages of forest loss in the 2000-2013 period were Brazil, Ecuador, Colombia, and Peru, with losses from $9.1 \%$ to $17.6 \%$ (RAISG, 2015). These losses are significant given that the Amazon rainforest plays an important role in global biodiversity conservation. Additionally, the Amazon River and its tributaries constitute one-fifth of the available freshwater resources in the world (UNESCO, 2006). Within this vast territory, Peru has lost an estimated $12 \%$ of its tropical forests, or approximately 10 million hectares (ha) since 1900 (HOTZ et al., 2015). Over the last several decades, numerous studies have been carried out to calculate deforestation rates in Peru. However, the generated data have simply served as a reference because they are not officially recognized by the Peruvian government. In 2012, with the implementation of the Monitoring of Deforestation, Forest Use, and Land-Use Changes in the Pan-Amazon Forest project by the Amazon Cooperation Treaty Organization (Organización del Tratado de Cooperación Amazónica [OTCA]) and the establishment of the Peruvian Observation Unit (Sala de Observación Perú [SdO]), the National Forest Conservation Program for Climate Change Mitigation (Programa Nacional de Conservación de Bosques para la Mitigación del Cambio Climático) of the Ministry of the Environment (Ministerio del Ambiente [MINAM]) and the National Forest and Wildlife

FLORESTA, Curitiba, PR, v. 49, n. 4, p. 859 - 868, out/dez 2019.

Llanos, L. R. C. et.al.

ISSN eletrônico 1982-4688

DOI: $10.5380 /$ rf.v49 i4.60160 
Service (Servicio Nacional Forestal y Fauna Silvestre) of the Ministry of Agriculture and Irrigation (Ministerio de Agricultura y Riego [MINAGRI]) jointly developed a methodology to analyze satellite images and standardize data on the Amazon forest at the national level (MINAM et al., 2014). In addition, a descriptive report was jointly elaborated, including a forest presence/absence map for 2000 and the 2000-2011 Amazon Rainforest Loss Map for Peru, finally providing official data on deforestation in Peru.

Notably, Peru is one of the ten countries in the world with the largest forest area. It also has the secondlargest extension of Amazon forest and the fourth largest extension of tropical forest (FAO, 2016). For this reason, the forests of Peru are an important carbon reservoir at the global level. Unfortunately, deforestation as a result of land-use practices, land-use changes, and silviculture (USCUSS) is responsible for the emission of $39 \%$ of the total greenhouse gases emitted in Peru in addition to causing the loss of biodiversity and ecosystem services (MINAM, 2015). In this regard, Peru, similar to several other countries, has committed itself to the global efforts to reduce greenhouse gas emissions. Accordingly, monitoring the state of forests along with implementing appropriate conservation strategies are indispensable. The scientific literature has reported that a variety of factors are related to deforestation, including population growth, poverty, land-use change to agriculture, and type of land tenure, among others (NEPSTAD et al., 2014). However, it is necessary to not only understand the causes of tropical deforestation but also to generate reliable data on deforestation and therefore gain a greater understanding of forest loss patterns and dynamics at a regional and local scale.

The present study analyzes the patterns of forest loss in 16 territorial categories and two types of land tenure (public and private) and administration (public and private) based on the current official data on forest loss in the Peruvian Amazon during the 2001-2016 period.

\section{MATERIALS AND METHODS}

\section{Study area}

The study area constitutes the Amazon rainforests of Peru according to the area defined by the joint collaboration of MINAM, MINAGRI, and SdO-OTCA. The basin headwaters represent the upper limit. This study includes 15 of the 24 administrative departments of Peru. In seven of these departments, the rainforest area has been highly reduced. In the base year of 2000 , the study area encompassed $78,308,801$ ha, corresponding to approximately $61 \%$ of the national territory (Figure 1 ).

\section{Forest definition}

According to MINAM et al. (2014), forests are a predominantly arboreous ecosystem with an area greater than 0.5 ha, a minimum width of 20 meters, and a minimum canopy cover of $10 \%$. Consequently, the forest presence/absence map in 2000 and the Peruvian Amazon rainforest loss map include the following areas as forest: primary forest (riparian forest, terraced forests, and hilly and mountainous forests), bamboo forests (Guadua spp.), palm forests (dominated by Mauritia flexuosa), and rod forests (forests with a high density of vertical stems and palms). Meanwhile, the following areas were not considered forest: secondary herbaceous forests, hydrophytic grasslands, agricultural and livestock areas, mining areas, population centers, infrastructure, and road networks.

\section{Delimitation of departments and territorial categories}

The utilized territorial categories are units created for territorial planning and management. The Peruvian government established eight territorial categories that are further grouped into 16 subcategories according to the level of conservation, use, and access to forest resources and protection status. These categories are represented by 195 natural protected areas (18,580,302 ha), 4,096 indigenous and subsistence farming communities $(12,444,063 \mathrm{ha})$, two territorial reserves that maintain the isolation of indigenous groups from initial contact $(1,689,497 \mathrm{ha}), 2,035$ forests for the permanent production of timber products $(7,586,589 \mathrm{ha})$ and nontimber products (2,075,092 ha), 76 permanent production forests in reserves (8,308,812 ha), 282 rural lands (748,432 ha), 20 special Amazon wetland conservation areas $(3,164,897 \mathrm{ha})$, and noncategorized areas $(14,422,645$ ha) (GEOBOSQUES, 2017). 


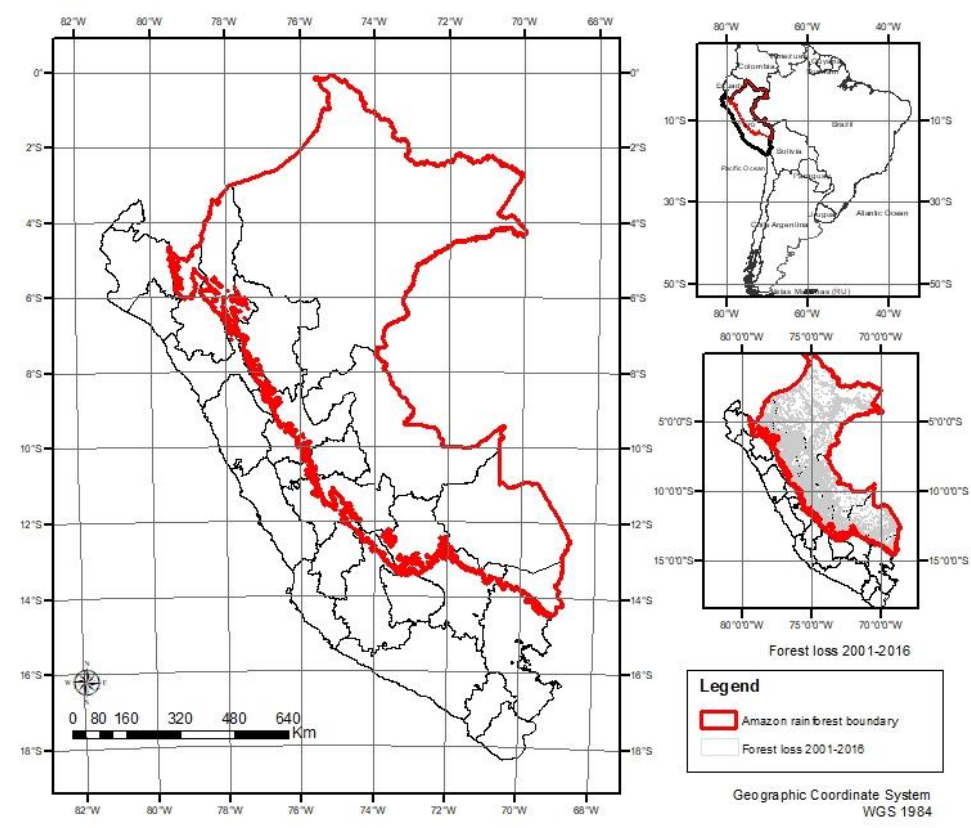

Figura 1. Mapa da área de estudo mostrando os limites do departamento e o mapa de perdas florestais para 2001 2016.

Figure 1. Map of the study area showing department boundaries and forest loss map for 2001-2016.

\section{Calculation of forest loss}

The Peruvian government annually presents official statistics on forest loss generated by cloud-free mosaic images from the Landsat-ETM+ sensor (level L1T). These images are geometrically rectified, free of sensor-related distortions and have a UTM projection. In the present study, the images were reprojected using a sinusoidal projection (central meridian of $60^{\circ} \mathrm{W}$ ) (MINAM et al., 2014) and were then calibrated to top-ofatmosphere reflectance values using the approach described by Chander et al. (2009). Then, the digital classification of the cloud-free mosaics was performed through a supervised classification with decision trees according to an algorithm designed by the University of Maryland. For this procedure, it is necessary to have samples or spectral training areas for the desired classes, which are set and examined manually (forest presence/absence). One pixel was considered the minimum mapping unit (MINAM et al., 2014), and the base year was 2000. Two classes were considered: forested areas and unforested areas. For each year in the 2001-2016 period, the same procedure was performed, yet the additional class of forest loss (each year) was added. After the classification was obtained for each year, the results were projected in UTM to generate freely available raster and vector maps (GEOBOSQUES, 2017).

\section{Temporal comparison of forest loss per department and territorial category}

To detect similar territorial categories and departments according to the proportion of forest loss in the 2001-2016 period, multivariate analyses were performed. The forest loss in each territorial category in each department $(n=15)$ and year $(n=16)$ was analyzed using cluster analysis, which is a convenient method for organizing a large multivariate data set and describing patterns of similarity and dissimilarity within the data (EVERITT; DUNN, 2001). The results of the Bray-Curtis similarity index were used to perform the clustering based on the group average linkage criterion (BRAY; CURTIS, 1957); it was not necessary to transform the data. The forest loss in each territorial category $(n=16)$ and each department and year $(n=240)$ was further analyzed using nonmetric multidimensional scaling (NMDS), which is an analytical tool that produces a spatial representation and ordination of data based on the first similarity matrix generated by the cluster analysis. This technique counters the disadvantages attributed to other ordination techniques, as it enables the use of distinct similarity indexes, preserves distance among samples, and can be used for nonparametric data. Accordingly, there are no theoretical assumptions that must be met, and there are no limitations for the amount of data that can be analyzed (MCCUNE; MEFFORD, 1997). To understand the contribution of each department and year to deforestation in each territorial category, a similarity percentage (SIMPER) analysis was performed considering type of land tenure and administration as factors (CLARKE; WARWICK, 1994). This latter analysis is based on calculating a similarity index between two samples wherein the contribution of each variable to the total similarity

FLORESTA, Curitiba, PR, v. 49, n. 4, p. 859 - 868, out/dez 2019.

Llanos, L. R. C. et.al.

ISSN eletrônico 1982-4688 
(or dissimilarity) between the pair of samples is expressed. The multivariate analyses were carried out in Primer software (Plymouth Routines in Multivariate Ecological Research) version 6.1.13 and the descriptive analyses in Minitab Statistical Software 17 (2010).

\section{RESULTS}

\section{Forest loss}

An estimated 1,974,209 ha of Peruvian Amazon forest was lost between 2001 and 2016. Forest loss peaked in 2009 (152,158 ha), 2014 (177,566 ha), and 2016 (164,662 ha). The lowest forest losses were recorded in 2003 (72,872 ha) and 2006 (74,499 ha). Between 2001 and 2006, the proportional forest loss (ha) per department was lowest in Ayacucho, Cajamarca, Huancavelica, La Libertad, Piura, and Puno, where the average and median values were similar and, most notably, below 0.01 ha. The departments with the highest proportion of forest loss (ha) during the 2001-2006 period are listed in decreasing order: San Martín ( $\bar{X}=0.21$ ha), Loreto ( $\bar{X}=0.19$ ha), Ucayali $(\bar{X}=0.16$ ha), and Huánuco $(\bar{X}=0.14)$. San Martín stands out given that more than $50 \%$ of its yearly proportional forest losses were equal to or greater than 0.21 ha. In Loreto, the average and median values were also similar, evidencing a similar and continual loss from year to year $(\mathrm{me}=0.19)$. In Ucayali, more than $50 \%$ of its values were equal to or greater than 0.17 ha. Similarly, for Huánuco, more than $50 \%$ of its values were equal to or greater than 0.14 (Figure 2).

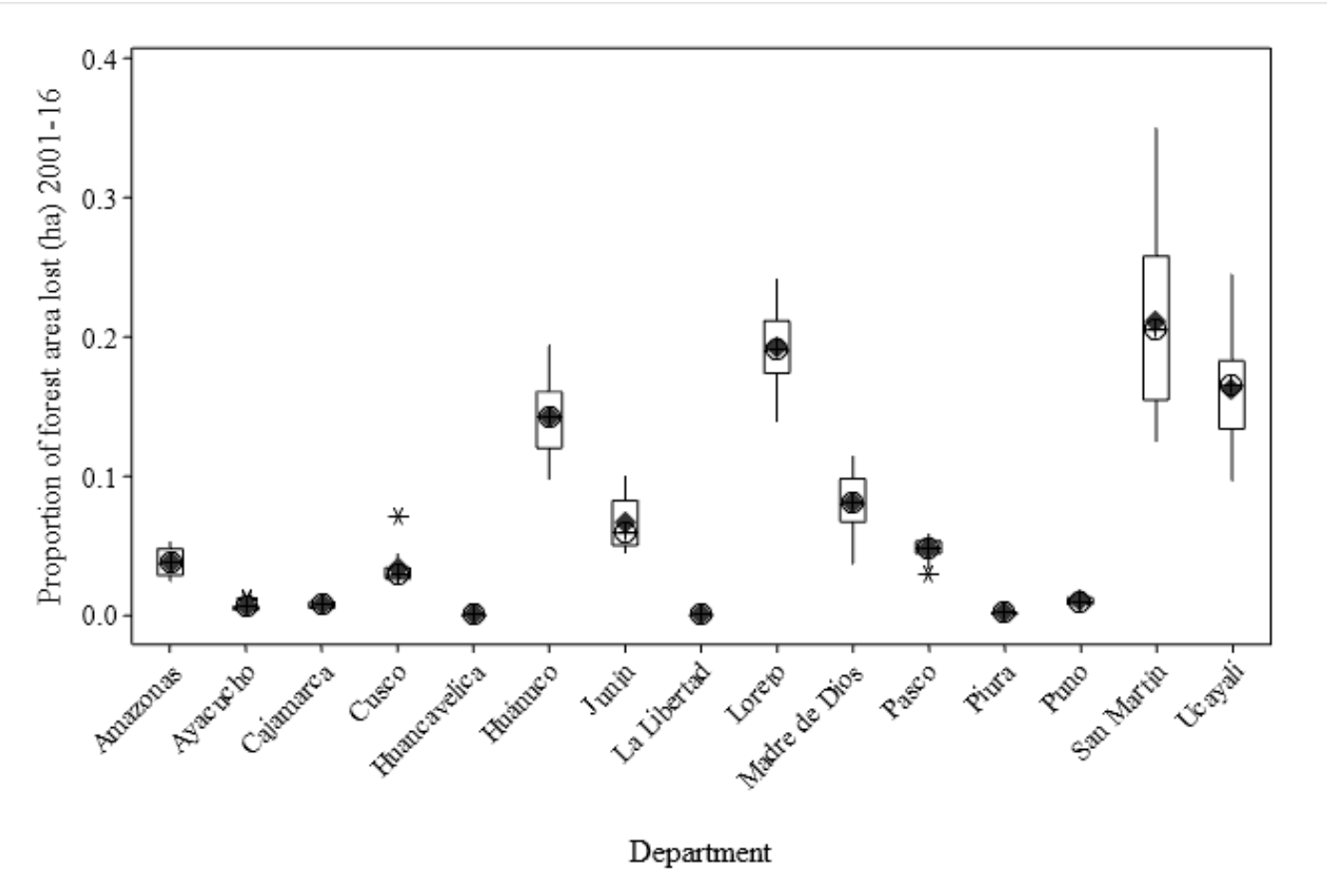

Figura 2. Perda de florestas na Amazônia peruana por departamento no período 2001-2016. Figure 2. Forest loss in the Peruvian Amazon per department in the 2001-2016 period.

The territorial categories that presented the greatest proportion of forest loss (ha) in the 2001-2016 period are listed in decreasing order: noncategorized areas (NCs; $\bar{X}=0.40 \mathrm{ha}$ ), indigenous communities with land titles (ICTs; $\overline{\mathrm{X}}=0.17$ ), rural lands (RLs; $\overline{\mathrm{X}}=0.14$ ), permanent production forests (PPFs; $\overline{\mathrm{X}}=0.12$ ), and timber concessions (TCs; $\overline{\mathrm{X}}=0.08$ ). The remaining categories had average proportional forest losses below 0.03 ha (Figure 3 ). 


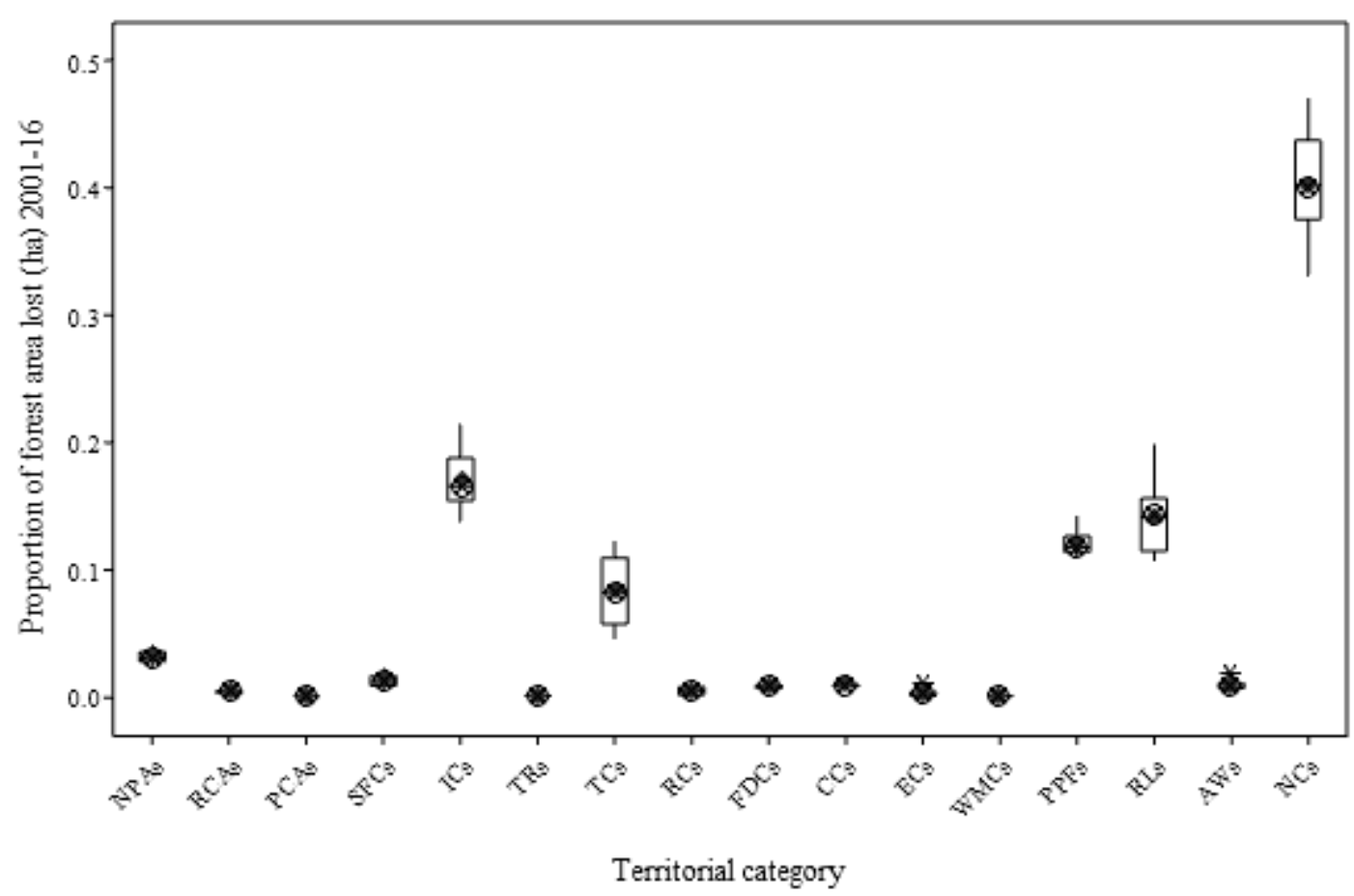

Figura 3. Perda florestal na Amazônia peruana por subcategoria territorial no período 2001-2016. NPAs: áreas naturais protegidas, RCAs: áreas regionais de conservação, PCAs: áreas privadas de conservação, SFCs: comunidades agrícolas de subsistência com títulos de terra, ICs: comunidades indígenas com títulos de terra, TRs: reservas territoriais que isolam grupos indígenas do contato inicial, TCs: concessões madeireiras, RCs: concessões de reflorestamento, FPCs: concessões de produtos florestais - castanhas-do-pará e seringueiras, CCs: concessões de conservação, ECs: concessões de ecoturismo, WMCs: concessões de áreas de manejo de vida selvagem, PPFs: florestas de produção permanente em reservas, RLs: terras rurais, AWs: Zonas úmidas amazônicas, NCs: áreas não categorizadas.

Figure 3. Forest loss in the Peruvian Amazon per territorial subcategory in the 2001-2016 period. NPAs: natural protected areas, RCAs: regional conservation areas, PCAs: private conservation areas, SFCs: subsistence farming communities with land titles, ICs: indigenous communities with land titles, TRs: territorial reserves that isolate indigenous groups from initial contact, TCs: timber concessions, RCs: reforestation concessions, FPCs: forest product concessions - Brazil nuts and rubber trees, CCs: conservation concessions, ECs: ecotourism concessions, WMCs: wildlife management area concessions, PPFs: permanent production forests in reserves, RLs: rural lands, AWs: Amazon wetlands, NCs: noncategorized areas.

\section{Temporal comparison of forest loss per department among territorial categories}

Given that two or more territorial categories can be present in a single department, we assumed that these categories were spaces where forest loss may or may not occur depending on the degree of protection, available financial resources and, especially, the location. The cluster analysis determined that the more similar departments $(>=80 \%)$ in terms of their proportion of forest loss (ha) in the 2001-2016 period were Pasco and Junín ( 82\%), Cusco and Amazonas ( 85\%), Ucayali and Huánuco (90\%), Puno and Cajamarca ( 82\%), and Libertad and Huancavelica $(\sim 80 \%)$ (Figure 4$)$. The SIMPER analysis divided the departments into three sectors based on location (northern, central, and southern sectors). The lowest similarity in forest loss (19.68\%) was detected in the departments in the northern sector; in this sector, $51.28 \%$ of the similarity was contributed in decreasing order by the years 2002, 2007, 2006, 2001, 2010, 2004, and 2016. The departments in the central sector had the highest similarity (65.08\%); in this sector, $54.37 \%$ of the similarity was contributed in decreasing order by the years 2005 , 2006, 2014, 2016, 2001, 2009, 2012, and 2011. Last, the departments in the southern sector had a similarity of $26.39 \%$; in this sector, $54.50 \%$ of the similarity was contributed in decreasing order by the years 2001, 2006, 2016, 2003, 2010, 2004, and 2014. 


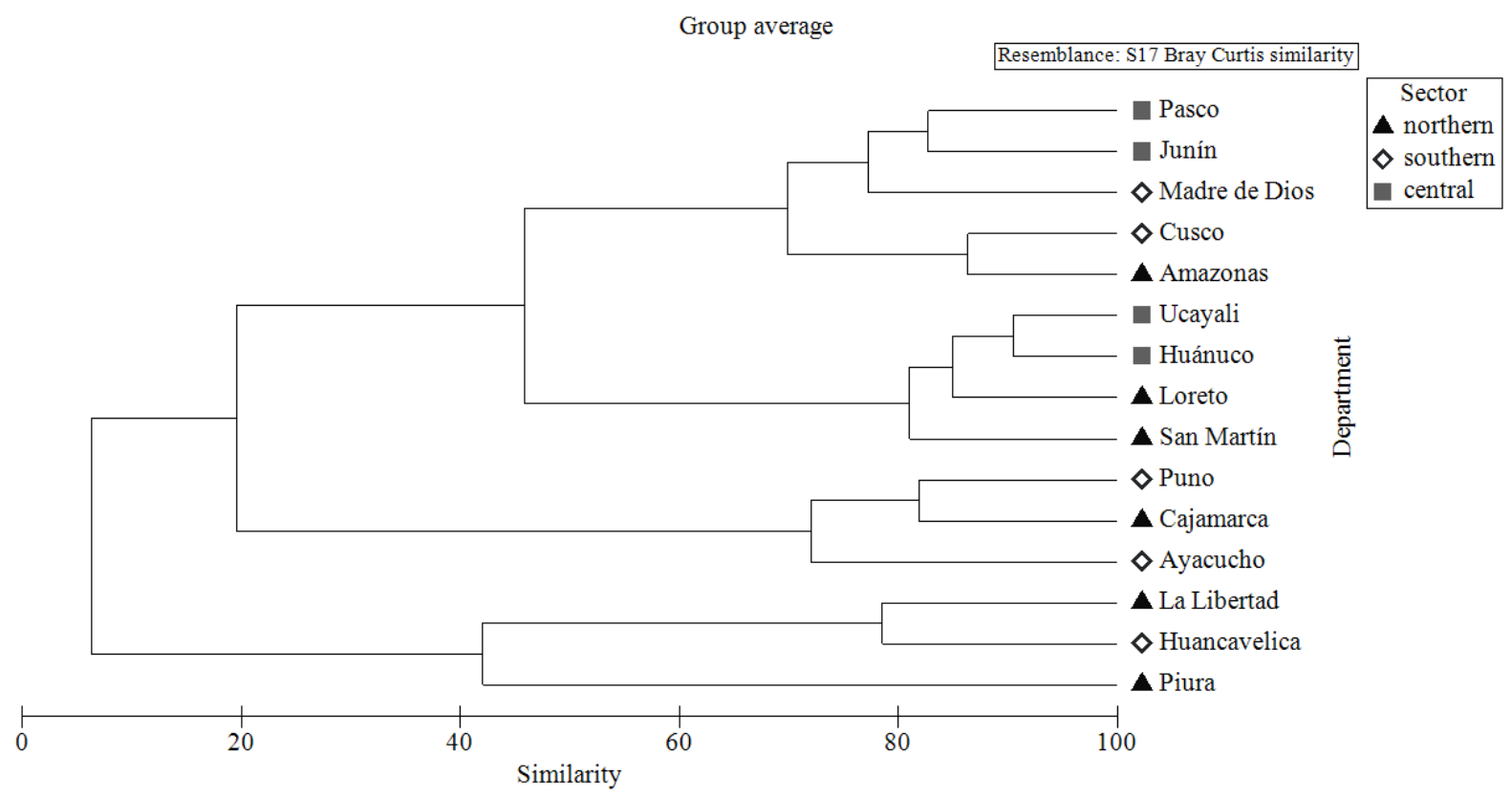

Figura 4. Análise de agrupamento da matriz de dados da proporção acumulada de perda florestal em cada departamento $(n=15)$ e ano $(n=16)$ usando o critério de ligação média do grupo e o índice de similaridade Bray-Curtis.

Figure 4. Cluster analysis of the data matrix of the accumulated proportion of forest loss in each department $(n=15)$ and year $(\mathrm{n}=16)$ using the group average linkage criterion and the Bray-Curtis similarity index.

The analysis of the goodness-of-fit of the NMDS of the proportion of forest loss (ha) in each territorial category $(n=16)$ and department and year $(n=240)$ shows a deforestation similarity of $80 \%$ between the forest product concessions (FPCs) of Brazil nuts and rubber trees and the reforestation concessions (RCs); these subcategories also show a $60 \%$ similarity with the ecotourism concessions (ECs). The regional conservation areas (RCAs) and the conservation concessions (CCs) presented 60\% similarity, similar to the natural protected areas (NPAs), indigenous communities with land titles (ICs), and noncategorized areas (NCs) (Figure 5). The subsistence farming communities (SFCs) with land titles had the most distinct pattern $(<20 \%)$ of forest loss over the measured years.

The percentage of similarity between territorial categories with respect to land tenure and administration per department and year was calculated using a SIMPER analysis. The obtained results are shown in Table 1. The dissimilarity between the territorial categories according to the land tenure criterion was $76.71 \%$. Meanwhile, according to the administration criterion, the dissimilarity was $73.22 \%$. 


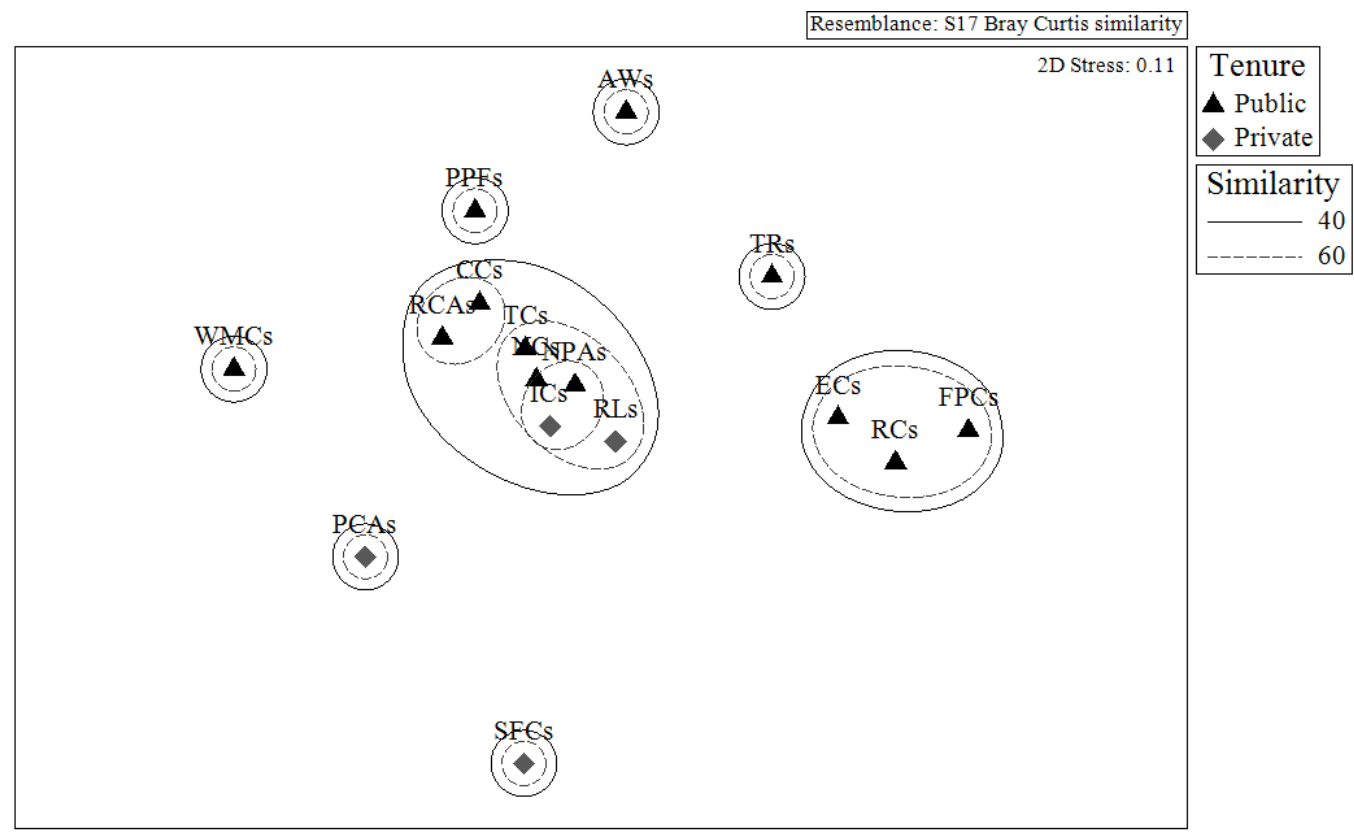

Figura 5. Ordenação NMDS usando o índice Bray Curtis calculado a partir de uma matriz de dados da proporção de perda florestal (ha) em cada categoria territorial $(n=16)$ por ano e departamento para o período 2001 2016 (estresse=0,11 em 2 dimensões, 5.000 reiterações). Ver abreviaturas na Figura 3. As linhas pontilhadas indicam os pontos de corte estabelecidos na análise de agrupamento realizada para esse fim.

Figure 5. NMDS ordination using the Bray Curtis index calculated from a data matrix of the proportion of forest loss (ha) in each territorial category $(n=16)$ per year and department for the 2001-2016 period (stress $=0.11$ in 2 dimensions, 5,000 reiterations). See abbreviations in Figure 3 . The dotted lines indicate the cut-off points established in the clustering analysis performed for this purpose.

Tabela 1. Contribuição para a perda florestal em cada departamento e ano para a similaridade entre as categorias territoriais de acordo com a posse e administração da terra para o período 2001-2016.

Table 1. Contribution to forest loss in each department and year to the similarity between territorial categories according to land tenure and administration for the 2001-2016 period.

\begin{tabular}{|c|c|c|c|}
\hline Criterion & Factor & $\begin{array}{c}\% \\
\text { similarity }\end{array}$ & $\begin{array}{l}\text { Initial department-year contributing to } 50 \% \text { similarity in each } \\
\text { factor* }\end{array}$ \\
\hline \multirow[b]{2}{*}{ Land tenure } & Public & $28.28 \%$ & $\begin{array}{l}\text { SMA-07, UCA-13, MDI-11, SMA-04, MDI-15, MDI-14, MDI-08, MDI- } \\
\text { 01, MDI-04, MDI-16, UCA-16, MDI-12, SMA-02, MDI-03, MDI-10, } \\
\text { MDI-07, LOR-16, SMA-10, SMA-06, SMA-09, SMA-05, SMA-01, } \\
\text { UCA-12, SMA-03, LOR-14, MDI-13 }\end{array}$ \\
\hline & Private & $25.97 \%$ & $\begin{array}{l}\text { SMA-07, SMA-10, AMA-03, SMA-08, AMA-07, SMA-09, SMA-04, } \\
\text { AMA-06, AMA-02, SMA-02, AMA-15, AMA-16, AMA-13, SMA-12, } \\
\text { SMA-05, AMA-08, SMA-11, SMA-06, SMA-01, AMA-04, PAS-14, } \\
\text { AMA-01, PAS-12, AMA-09, PAS-13, PAS-05, PAS-06, SMA-03, CUS- } \\
\text { 06, AMA-14, SMA-15, PAS-09, AMA-12, PAS-10, SMA-13 }\end{array}$ \\
\hline \multirow{2}{*}{ Administration } & Public & $32.90 \%$ & $\begin{array}{l}\text { LOR-16, LOR-14, LOR-10, UCA-13, LOR-13, UCA-12, SMA-07, UCA- } \\
\text { 15, LOR-06, UCA-11, LOR-12, LOR-15, LOR-04, UCA-16, UCA-09, } \\
\text { UCA-14, UCA-08, UCA-05, UCA-03, LOR-09, LOR-02, LOR-08, UCA- } \\
\text { 06, SMA-04, LOR-11 }\end{array}$ \\
\hline & Private & $23.10 \%$ & $\begin{array}{l}\text { MDI-15, MDI-10, MDI-08, MDI-11, MDI-04, MDI-16, SMA-07, MDI- } \\
\text { 14, SMA-10, SMA-04, MDI-03, MDI-07, MDI-02, SMA-12, MDI-12, } \\
\text { MDI-01, SMA-01, SMA-08, SMA-09, MDI-13, SMA-11, MDI-06, } \\
\text { SMA-02, MDI-05 }\end{array}$ \\
\hline
\end{tabular}

*=AMA: Amazonas; CUS: Cusco; LOR: Loreto; MDI: Madre de Dios; PAS: Cerro de Pasco; SMA: San Martín; UCA: Ucayali. 


\section{DISCUSSION}

Deforestation in the Peruvian Amazon shows a tendency to annually increase in all territorial categories and departments. Forest loss peaked in 2009, 2014, and 2016. After dividing the country into three regional sectors, similarity was only observed in the departments in the central sector, such as Cerro de Pasco and Junín, which may be related to their similar socioeconomic characteristics and land uses. On the other hand, the similarity found between the departments in different sectors, such as Cusco and Amazonas, Ucayali and Huánuco, Puno and Cajamarca, and La Libertad and Huancavelica, highlights that despite not being adjacent, with the exception of Ucayali and Huánuco, these departments may share similar agricultural or land uses.

Forest loss occurred in all of the territorial categories in Peru, including those with defined land tenure and assigned property rights. The noncategorized areas constitute the territorial category with the second-largest Amazon forest area $(21 \%)$ in Peru. These areas also experience the greatest forest loss, coinciding with the Peruvian government report that $40 \%$ of deforestation is concentrated in these areas (GEOBOSQUES, 2017). Furthermore, as these areas do not have defined land tenure or assigned property rights, it is more difficult to regulate their access and use. Research affirms that areas with unclear land tenure, especially forests, can be more prone to degradation (CHOMITZ et al., 2007), which may be similar to what is occurring in the noncategorized areas in Peru. Even though degradation and deforestation are linked to a complex array of socioeconomic and political factors, land tenure and land security, which refer to the existence of secure and clear land and land-use rights, tend to be considered among the most influential factors (ROBINSON et al., 2014; HOLLAND et al., 2014). Likewise, forest tenure, understood as the set of rules, institutions, and policies that determine how land and its resources are accessed, maintained, and used (BRUCE et al., 2010; LARSON et al., 2010), has gained increasing research interest. Even so, despite the recognized impact of land tenure on forests, the relationship between tenure and deforestation remains, being ambiguous in many cases (CHOMITZ et al., 2007; BLACKMAN et al., 2014).

In addition, the analyzed data highlight indigenous communities as the territorial category with the second-highest accumulated deforestation during the study period. Other studies (BLACKMAN et al., 2017) have shown that indigenous territories tend to prevent forest loss as much as or more than protected areas, apparently contradicting the results of the present analysis. This difference may be due to the official Peruvian methodology of calculating forest loss, which identifies forest and nonforest areas in satellite images based on their reflectance values. However, this methodology does not consider, for example, the natural successional changes of riparian forests, where indigenous communities regularly settle and cause large forest losses. In addition, although indigenous communities possess titles to their lands, they do not have secure tenure over their territory and resources, as their rights are often superimposed by those assigned to mining concessions, petroleum concessions, or industrial agricultural productions.

Furthermore, this study showed that natural protected areas have a lower rate of deforestation than the other territorial categories. However, this low rate may be related to the location, low accessibility, or other characteristics of these areas that protect them from human exploitation (JOPPA et al., 2008; BEBBER et al., 2017). In this respect, it would be important to analyze whether this barrier to deforestation is due to de facto or de jure protection (JOPPA et al., 2008).

The aforementioned findings outline the need to analyze in great detail and depth how forests and their resources are accessed, how forests and their resources are used and managed, and which decisions are made about forests. Additionally, it is necessary to implement multisectoral territorial planning and coherent policies that respond to the actual national scenario of deforestation. Although the forest loss between areas with public and private tenure showed a low similarity $(<30 \%)$, similar to other types of administration, additional factors may be affecting deforestation in the different territorial categories.

Finally, the similar pattern of deforestation in each territorial category over the last five years coincides with the implementation of incentive policies for development activities in the Peruvian Amazon (PAUTRAT; MERVEILLE, 2014), suggesting that such policies could have contributed to land-use changes. On the other hand, the finding that noncategorized areas do not affect the general tendency of deforestation in Peru is particularly interesting because the dynamics of forest loss are similar in other territorial categories with assigned rights, even though noncategorized areas are facing the highest rate of deforestation. Accordingly, the need to assign clear tenure and rights over natural resources is evidenced in addition to the need to examine the existing norms governing access to resources in the established territorial categories to have greater control over forest loss. A final interesting finding is that the years 2006 and 2016, which corresponded with political changes and the inclusion of new regulations in the Forests and Wildlife Law in Peru, showed the greatest forest loss at the departmental level and in the territorial categories. 


\section{CONCLUSIONS}

- In the last 15 years, forest loss in the Peruvian Amazon has increased despite the measures adopted and commitments ratified by the national government. It is urgent to revise the nonforest class defined by the official methodology of the Peruvian government and to consider natural processes and natural forest succession when defining forest/nonforest classes. Similarly, the minimum mapping unit $(30 \times 30 \mathrm{~m})$ should be revised to improve the precision and accuracy of forest maps, as it likely exaggerates the deforested area. These changes would enable the implementation of more adequate preventative actions.

- The departments with the lowest forest loss were Ayacucho, Cajamarca, Huancavelica, La Libertad, Piura, and Puno. However, it is important to consider that these departments also have a small forest area because they are located at the outer limits of the Amazon watershed. Accordingly, the total surface area of these departments was not evaluated.

- The similarity in forest loss in some departments is probably related to their spatial proximity, similar land uses, socioeconomic dynamics, and customs of their inhabitants, among other factors. It is necessary to establish measures for similar areas to control, supervise, and sustainably use forest resources, especially for the public tenure categories affected by deforestation.

- The years showing forest loss at all levels (departmental, territorial, tenure and administration) were 2006 and 2016. In these years, governmental changes occurred in Peru, including modifications to the forest law and its associated regulations.

- Finally, it was possible to identify forest loss patterns and similarities across departments and territorial categories through a series of statistical techniques that enabled the exploration and visualization of forest loss data at the national level. This methodology can be used as a tool for decision making regarding forest resources at the local, regional, and national levels.

\section{ACKNOWLEDGMENTS}

Peru Observation Unit (Sala de Observación Perú [SdO-OTCA]) - Engineer Carlos Salinas Montes. Álvaro Claros Canales and Sheila Gamarra Agama for their support in the generation of thematic layers and maps.

\section{REFERENCES}

BEBBER, D. P.; BUTT, N. Tropical protected areas reduced deforestation carbon emissions by one third from 20002012. Scientific Reports, vol. 7, n. 14005, p. 1-7, 2017.

BLACKMAN, A.; EPANCHIN-NIELL, R.; SIIKAMAKI, J.; VELEZ-LOPEZ, D. Biodiversity Conservation in Latin America and the Caribbean: Prioritizing Policies. Resources for the Future Press, New York. 2014. 180 p.

BLACKMAN, A.; CORRAL, L.; SANTOS LIMA, E.; ASNER, G. P. Titling indigenous communities protects forests in the Peruvian Amazon. Proceedings of the National Academy of Sciences of the United States of America, United States of America, v. 114, n. 16, p. 4123 - 4128, 2017.

BRAY, J. R.; CURTIS, J. T. An ordination of the upland forest communities of Southern Wisconsin. Ecological Monographs, United States of America, v. 27, p. 325 - 349, 1957.

BRUCE, J. W.; WENDLAND K, J.; NAUGHTON-TREVES, L. Whom to pay? Key Concepts and Terms Regarding Tenure and Property Rights in Payment-based Forest Ecosystem Conservation. Land Tenure Center, University of Wisconsin, Madison, WI, United States of America, Tenure brief 15, p. 1 - 10, 2010.

CHANDER, G.; MARKHAM, B. L.; HELDER, D. L. Summary of current radiometric calibration coefficients for Landsat MSS, TM, ETM+, and EO-1 ALI sensors. Remote Sensing of Environment, United States of America, v. 113, p. $893-903,2009$.

CHOMITZ, K. M.; BUYS, P.; DE LUCA, G.; THOMAS, T. Y.; WERTZ-KANOUNNIKOFF, S. At loggerheads? Agricultural expansion, poverty reduction, and environment in the tropical forests. Policy Research Report. Banco Mundial, Washington, DC. United States of America, 2007, 308 p.

CLARKE, K. R.; WARWICK, R. M. Change in marine communities. An approach to statistical analysis and interpretation. United Kingdom. Natural Environmental Research Council. 2 ed. 2001, 176 p.

EVERITT, B. S.; DUNN, G. Applied multivariate data analysis. London, United Kingdom: Arnold, v. 2, 2001, 337 p.

FOOD AND AGRICULTURE ORGANIZATION (FAO). Estado de los bosques del mundo: Los bosques y la Agricultura: desafíos y oportunidades en relación con el uso de la tierra [State of the world's forests: Forests and agriculture: challenges and opportunities in land use]. Rome, Italy: FAO, 2016, 137 p.

FLORESTA, Curitiba, PR, v. 49, n. 4, p. 859 - 868, out/dez 2019.

Llanos, L. R. C. et.al.

ISSN eletrônico 1982-4688 
GEOBOSQUES. Plataforma de monitoreo de los cambios sobre la cobertura de los bosques [Platform for monitoring the changes in forest cover]. 2017. Available at: <http://geobosques.minam.gob.pe/geobosque/view/index.php/> Accessed on: 01 Dec. 2017.

HOLLAND, M. B.; DE KONINF, F.; MORALES, M.; NAUGHTON-TREVES, L.; ROBINSON, B. E.; SUÁREZ, L. Complex Tenure and Deforestation: Implications for Conservation Incentives in the Ecuadorian Amazon. World Development, United States of America, v. 55, p. 21 - 36, 2014.

HOTZ, H; CHABANEIX, G.; GUARÍN, A. Interpretación de la dinámica de la deforestación en el Perú y lecciones aprendidas para reducirla [Interpretation of the deforestation dynamics in Peru and lessons learned to reduce deforestation]. Global Green Growth Institute, Lima, Peru. 2015, 42 p.

JOPPA, L. N.; LOARIE, S. R.; PIMM, S. L. On the protection of "protected areas". Proceedings of the National Academy of Sciences of the United States of America, United States of America, v. 105, p. 6673 - 6678, 2008.

LARSON, A. M.; BARRY, D.; DAHAL, G. R. Cambios en los patrones de tenencia en los países en desarrollo [Changes in tenure patterns in developing countries]. In: LARSON, A. M.; BARRY D.; DAHAL, G. R.; COLFER, C. J. P. Bosques y derechos comunitarios: Las reformas en la tenencia forestal [Forests and community rights: Forest tenure reforms]. Bogor, Indonesia: CIFOR, 2010, p. 3 - 20.

MCCUNE, B.; MEFFORD, M. J. Multivariate analysis of ecological data. Version 3.15 MJM Software, Gleneden Beach, Oregon, 1997.

MINAM, Ministerio del Ambiente. Programa Nacional de Conservación de Bosques para la Mitigación del Cambio Climático; MINAGRI, Ministerio de Agricultura y Riego; SdO-PERÚ, Sala de Observación Perú OTCA. Memoria Descriptiva del Mapa de Bosque/ No Bosque año 2000 y Mapa de pérdida de los Bosques Húmedos Amazónicos del Perú 2000-2011 [Descriptive Report of the 2000 Forest Presence/Absence Map and 2000-2011 Rainforest Loss

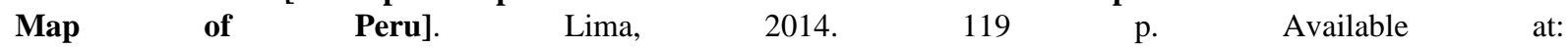
http://geobosques.minam.gob.pe/geobosque/view/descargas.php\#download> Accessed on: 01 Dec. 2017.

MINAM, Ministerio del Ambiente. Estrategia Nacional ante el Cambio Climático [National Climate Change Strategy]. Lima, Perú. 2015. 88 p. Available at: <http://www.minam.gob.pe/wp-content/uploads/2015/09/ENCCFINAL-250915-web.pdf $/>$ Accessed on: 01 Dec. 2017.

NEPSTAD, D.; MCGRATH, D.; STICKLER, C.; ALENCAR, A.; AZEVEDO, A.; SWETTE, B.; BEZERRA, T.; DIGIANO, M.; SHIMADA, J.; MOTTA, R.; ARMIJO, E.; CASTELLO, L.; BRANDO, P.; HANSEN, M.; MCGRATHHORN, M.; CARVALHO, O.; HESS, L. Slowing Amazon deforestation through public policy and interventions in beef and soy supply chains. Science, United States of America, v. 344, n. 6188, p. 1118 - 1123, 2014.

OTCA, Organización del Tratado de la Cooperación Amazónica. El cambio climático en la región Amazónica [Climate change in the Amazon region]. Acciones de la Organización del Tratado de la Cooperación Amazónica [Actions of the Amazon Cooperation Treaty Organization]. 2014. Available at: < http://www.otca.info/portal/admin/_upload/publicacoes/531 libro.cambio.climatico_esp.pdf /> Accessed on: $10 \mathrm{Jul}$. 2017.

PAUTRAT, L.; MERVEILLE, N. Incidencia de las políticas económicas en la transformación de la Amazonía peruana en un paisaje industrial [Incidence of economic policies in the transformation of the Peruvian Amazon in an industrial landscape]. Research document n. 2. Universidad Antonio Ruiz de Montoya. Lima, Peru, 1 ed. 2014, $22 \mathrm{p}$.

RAISG, Red Amazónica de Información Socioambiental Georreferenciada. Mapa Amazonía 2015. Áreas protegidas y Territorios Indígenas [2015 Amazon Map. Protected areas and indigenous territories]. Deforestación 2000 - 2013 [2000-2013 Deforestation]. Deforestación en la Amazonia 1970 - 2013 [1970-2013 Amazon Deforestation]. São Paulo: Instituto Socioambiental. 2015, 25 p.

ROBINSON, B. E.; HOLLAND, M. B.; NAUGHTON-TREVES, L. Does secure land tenure save forests? A metaanalysis of the relationship between land tenure and tropical deforestation. Global Environmental Change, Amsterdam, v. 29, p. $281-293,2014$.

UNESCO, United Nations Educational, Scientific and Cultural Organization. 2nd United Nations world water development report: water, a shared responsibility. UNESCO Publishing. 2006. Available at: <http://www.unesco.org/new/en/natural-sciences/environment/water/wwap/> Accessed on: 10 Jan. 2017.

WALKER, W.; BACCINI, A.; SCHWARTZMAN, S.; RÍOS, S.; OLIVEIRA-MIRANDA, M. A.; AUGUSTO, C.; CAMPOS, E. V. Forest carbon in Amazonia: the unrecognized contribution of indigenous territories and protected natural areas. Carbon Management, United States of America, v. 5, n. 5 - 6, p. 479 - 485, 2014. 